\title{
Lower and Middle Ordovician conodont diversity of the Yichang Region, Hubei Province, Central China
}

\author{
RONGCHANG WU, SVEND StOUGE, ZHIHONG LI \& ZHIAHAO WANG
}

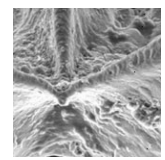

A survey on the (palaeo-) diversity of the Lower and Middle Ordovician conodont faunas from the Yichang Region, Hubei Province, Central China is presented. Analysis of the number of species through time shows the species richness is cyclical developed in the succession - varying from low to high. One major conodont diversity peak is recorded in the mid to late Floian Stage (Oepikodus evae Zone, stage slice Fl 2, Lower Ordovician), where 33 species are recorded in the lower unit of the Dawan Formation. A smaller but second high diversity is found in the Darriwilian Stage (Lenodus variabilis Zone; stage slice Da 2, Middle Ordovician) with a maximum of 23 species. Secondary, smaller diversification maxima are present in the early Tremadocian, late Tremadocian, early Dapingian and late Darriwilian stages. Current information on acritarchs, brachiopods, and trilobites shows that the highest diversity maximum of conodonts corresponds to a similar high in brachiopod diversity, whereas acritarch and trilobite maximum diversity appear after the conodonts/brachiopods in the region. - Keywords: diversity, Ordovician, conodonts, Yichang Region, Central China.

WU, R., STOUge, S., LI, Z. \& WANG, Z. 2010. Lower and Middle Ordovician conodont diversity of the Yichang Region, Hubei Province, Central China. Bulletin of Geosciences 85(4), 631-644 (4 figures, 1 electronical appendix). Czech Geological Survey, Prague. ISSN 1214-1119. Manuscript received February 10, 2010; accepted in revised form July 20, 2010; published online December 2, 2010; issued December 20, 2010.

Rongchang Wu, Nanjing Institute of Geology and Palaeontology, CAS, State Key Laboratory of Palaeontology and Stratigraphy, Nanjing 210008, China, and Geological Museum, University of Copenhagen, Øster Voldgade 5-7, DK-1350 Copenhagen K, Denmark; wu.rongchang@gmail.com•Svend Stouge, Geological Museum, University of Copenhagen, Øster Voldgade 5-7, DK-1350 Copenhagen K, Denmark; svends@snm.ku.dk・Zhihong Li, Yichang Institute of Geology \& Mineral Resources, Yichang, Hubei 443003, China • Zhiahao Wang, Nanjing Institute of Geology and Palaeontology, CAS, State Key Laboratory of Palaeontology and Stratigraphy, Nanjing 210008, China

The knowledge of conodont diversification in the Ordovician is at a fairly immature stage. Previous information includes Sweet (1988), a recent global review by Albanesi \& Bergström (2004), and Wu et al. (2010), who reported on the conodont biodiversity from the Zitai Formation in East China. Stouge et al. (2009) presented a brief comparison of the development of diversity between South China and Baltica. One conclusion from these investigations is that a high level of conodont diversification is recorded from both South China (Wu et al. 2010) and Baltica (Stouge et al. 2009), but is also observed on a global scale in the Floian Stage (Albanesi \& Bergström 2004). Hence a maximum conodont diversification peak indeed occurred both regionally and on a global scale in the Floian Stage.

In this paper we present the diversity details based on data from four sections in the Yichang Region, Hubei Province, Central China. The purpose is to present a faunal list of the principal conodont genera and species known from the Yichang region as a starting point for an estima- tion of the conodont palaeobiodiversity from the South China palaeoplate.

\section{Geological setting}

The South China palaeoplate was a peri-Gondwana continental terrane located at low to mid high latitude of the southern hemisphere (Metcalfe 1998, Cocks \& Torsvik 2004). It is composed of the Yangtze Platform, the Jiangnan Transitional Belt at the platform margin and the Zhujiang Basin. Important changes in litho- and biofacies on the South China palaeoplate are developed and collectively, they comprise a transect from near shore shallow water sediments to deep water offshore and distal deposits composed of mainly fine-clastic sediment or shale (Zhan \& Jin 2007). The Yichang area lies within the portion of the Yangtze Platform on the South China palaeoplate, where the succession is largely composed of shallow to mainly intermediate water carbonates with interbeds of deeper water 
mudstone that accumulated in an outer shelf setting (Zhan \& Jin 2007).

\section{Yichang Region, Central China}

The Yichang region (Fig. 1) in western Hubei is an area, where palaeontological studies on Ordovician faunas have been carried out since the $19^{\text {th }}$ century. During the later $19^{\text {th }}$ and the first part of the $20^{\text {th }}$ century numerous authors published monographs and faunal lists, especially of conodonts, brachiopods, and trilobites. Several conodont studies were published (e.g. An 1981, 1987; An et al. 1981, 1985; Ni 1981; Zeng et al. 1987; Wang \& Bergström 1995, 1998, 1999; Wang et al. 1996; Zhang 1996, 1997; Wang et al. 1993, 2005, 2009; Zhang 1998; Li et al. 2004b).

Observations on the diversity of acritarchs, brachiopods, and trilobites from the Yangtze Platform, including the Yichang Region, are made by Brocke (1997), Brocke et al. (2000), Li et al. (2004a, 2007), Zhan et al. (2006) and Turvey (2005). These papers provide a basis for discussing possible causes of variation in the diversification in these fossil groups over time.

\section{Geography and geology of the Yichang Region}

The focus of the study is the Yichang Region in the Hubei Province, Central China (Fig. 1). The Ordovician conodont faunas of the Yichang Region are known from mainly four closely spaced sections: the Huanghuachang, Chenjiahe, Puxihe, and Fenxiang sections (Fig. 1) (An 1987, Lindström et al. 1991, Schmitz et al. 2008, Wang et al. 2009, Zhang 1999). Generally, the yield of conodonts from these sections is high, but research on conodonts from the sections is not yet completed (Stouge et al. in prep.)

\section{Stratigraphy}

The Ordovician deposits in the Yichang Region are composed of carbonate facies with important reefal development beginning in the Tremadocian and culminating in the early Floian. The succession continues with intermixed carbonate and siliceous facies in the higher beds. Most recent and detailed information on the lithostratigraphy, formations, and development of the Yangtze platform to slope facies is outlined by Zhan \& Jin (2007) and Wang et al. (2009) (Fig. 2), which also includes a detailed list of references. The top Cambrian to early Late Ordovician stratigraphy of the Yichang Region (Fig. 1) may be outlined as follows:

Nantsinkuan Formation. - This is $160.5 \mathrm{~m}$ thick. It consists of grey to dark-grey wacke and grainstone, oosparitic limestone, cherty limestone, dolostone and bioclastic limestone. Most of the formation is referred to the Lower Ordovician, stage slice $\operatorname{Tr} 1$, whereas the lower-most part belongs to the Cambrian (Dong 1985).

Fenhsiang Formation. - Fenhsiang Formation, $49.7 \mathrm{~m}$ thick, includes two members. The lower member is composed of grey to black wackestone intercalated with yellow to green shale. The upper member consists of yellow to green shale interbedded with grey wacke- and grainstone. The formation is contained in the stage slices $\operatorname{Tr} 2$ and $\operatorname{Tr} 3$.

Hunghuayuan Formation. - This formation, $25 \mathrm{~m}$ thick, consists of mainly (light-) grey wackestone and grainstone, but is characterized by microbial-lithistid sponge-receptaculitid carbonate mounds (Lindström et al. 1991, Adachi et al. 2009). Oncoids and Girvanella limestone are common in the upper part of the succession. The upper boundary is placed where the mounds disappear. The most common bioclasts are echinoderms and trilobites. The formation is correlated with the basal Floian Stage (= stage slice Fl 1).

Dawan Formation. - The Dawan Formation conformably overlies the Hunghuayuan Formation. It is $\mathrm{ca} 37 \mathrm{~m}$ thick (Lindström et al. 1991). It is composed of grey wackestone, nodular bedded shale and limestone, reddish wackestone, and shale with interbeds of grey to yellow shale. Three members are distinguished (Zeng et al. 1983; Lindström et al. 1991; Turvey \& Zhou 2002; Wang et al. 2005, 2009). Lower member: The lower part of this member contains glauconitic grainstone, which is succeeded by yellow-grey to green shale and intercalated with grey lenticular bedded limestone (wackestone/grainstone) and nodular limestone. The member is very rich in brachiopods (=Didymograptellus eobifidus to Corymbograptus deflexus graptolite Zones; Zhan \& Harper 2006) and trilobites are present (Turvey \& Zhou 2002). The fauna and flora is composed of mixed warm and temperate (oceanic) water biota. The Floian-Dapingian stage boundary (Lower-Middle Ordovician Series boundary) is placed within the upper part of the lower member (Wang et al. 2009).

Middle member: This middle unit, $c a 13$ m thick, consists of purple, grey to weak red medium bedded limemudstone and wackestone and with minor green shale interbeds. Discontinuity surfaces (sensu Jaanusson 1961) are prominently developed throughout the unit (Lindström et al. 1991). Cephalopods are common and characteristic of the middle member (= Protocycloceras Zone). The middle member of the Dawan Formation largely corresponds to stage slice Dp 2 [= Isograptus (v.) maximus graptolite Zone].

Upper member: This unit is about $27 \mathrm{~m}$ thick. It is composed of yellow to green shale, nodular limestone and 

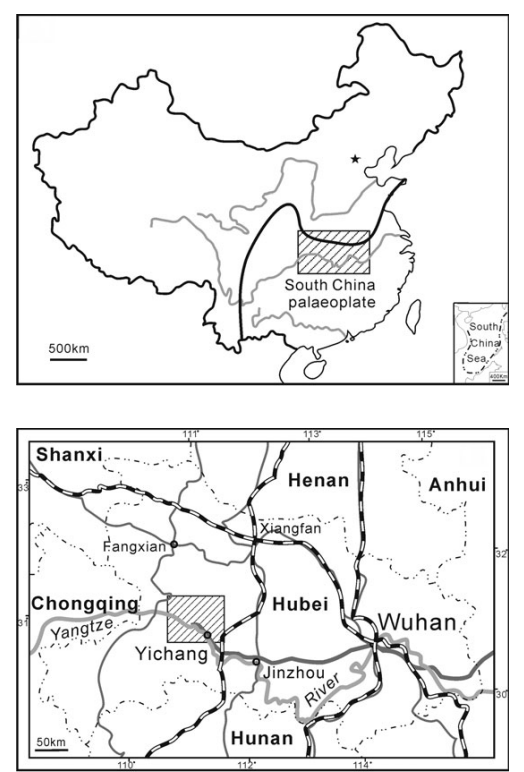

A

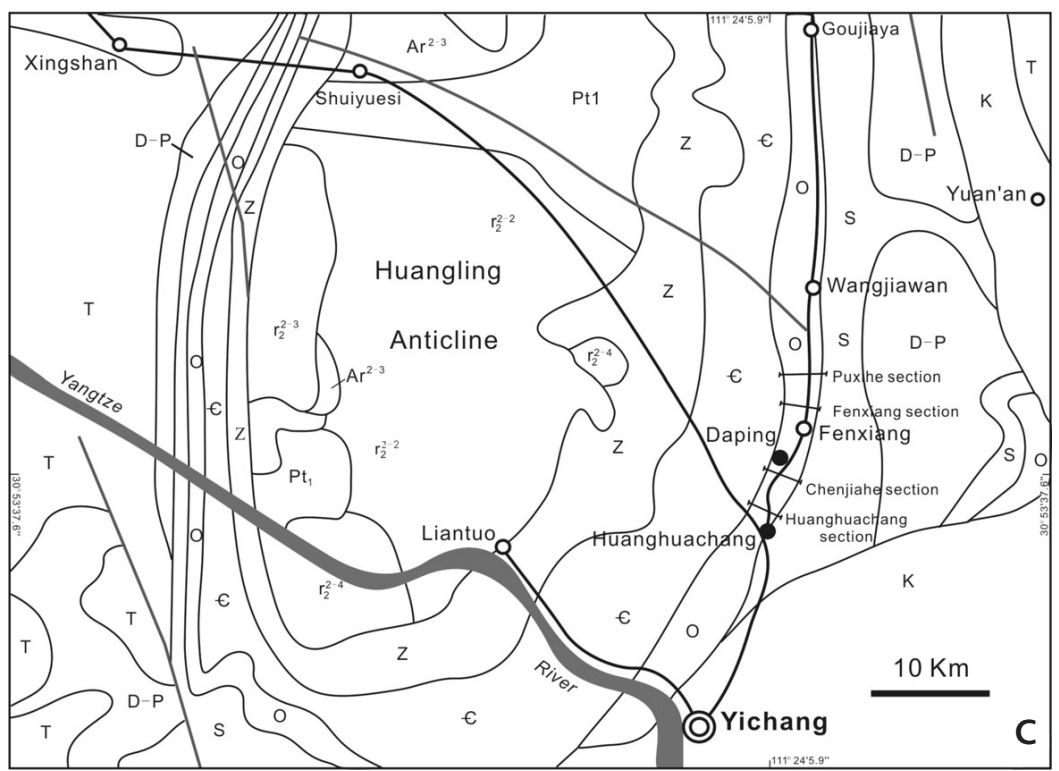

Figure 1. Geology and location map of the Yichang Region, Hubei Province, Central China. All four sections investigated here are situated close to the small town of Daping.

('dirty') lime-mudstone. Graptolites of the Undulograptus sinodentatus Zone are present in the lower part of the unit. Elements of the Undulograptus austrodentatus graptolite Zone are recorded near the top of the upper unit. Trilobites are characterized by displaying the highest diversity in this interval of the Dawan Formation (Turvey \& Zhou 2002).

Kuniutan Formation. - The Kuniutan Formation at Daping overlies conformably the Dawan Formation. It is composed of 19 to $21 \mathrm{~m}$ grey to light red micrite and wackestone, silty nodular wackestone, and grey wackestone (Lindström et al. 1991, Zhang 1996). Discontinuity surfaces are frequent. Cephalopods are common in the succession, and trilobites and echinoderm remains are present. The Kuniutan Formation is here subdivided into three members although Zhang (1996) subdivided the formation into five lithological units (Nanya, Puxi, Wuguixi, Daping and Xiangjiafang members) at the Fenxiang section.

Lower member: The lower member is $\mathrm{ca} 7 \mathrm{~m}$ thick and composed of medium bedded, grey to purplish red wackestone with subordinate nodular to marly beds. Orthocones are the most conspicuous in the member, but echinoderms and trilobites are the most common allochems.

Middle member: This unit mainly consists of nodular bedded limestone and siltstone intercalated with beds of limestone, ca $7.5 \mathrm{~m}$ thick. Small 'sheet-like' structures ('mini mounds' sensu Lindström et al. 1991) and fold structures (= 'buckled beds' of Lindström et al. 1991) characterize the middle part of the Puxi member (Lindström et al. 1991, Zhang 1996). Schmitz et al. (2008) recorded high concentrations of L-chondrites in the middle member from the Puxihe section; the concentration of L-chondrites is found within the Lenodus variabilis and Yangtzeplacognathus crassus conodont zones of Zhang (1998).

Upper member: This member is composed of medium bedded, grey wackestone. The unit is ca $4-5 \mathrm{~m}$ thick. A distinct interval with layers of laminated stromatoids is developed in the unit (Lindström et al. 1991).

Miaopo Formation. - The Miaopo Formation is about $2.3 \mathrm{~m}$ thick. It overlies the Kuniutan Formation and is composed mainly of black shale interbedded with thick beds of lime-mudstone. The Miaopo Formation spans the Darriwilian/Sandbian stage boundary (the Glyptograptus teretiusculus Zone is recorded in basal part and Nemagraptus gracilis Zone is present in the higher beds).

\section{Conodont zones in the Yichang Region}

The conodont zonation used here is a combination of the zonation schemes by An (1981, 1987), An et al. (1981, 1985), Dong (1985), Zhang (1998), Wang \& Bergström (1995), Zhen et al. (2009) and Wang et al. (2007, 2009) and it follows as closely as possible to the original definitions (Fig. 2). Some changes have been made for the purpose of this paper, and including the addition of the informal zones Zone A (unnamed) and Periodon flabellum Zone. Some zonal names are changed according to recent taxonomical revisions of nominate taxa (Fig. 2).

\section{Cambrian}

The conodont fauna recorded immediately below the base 
of the Ordovician includes Cordylodus proavus and Eoconodontus notchpeakensis (Table 1 - electronical appendix, see www.geology.cz/bulletin/contents) corresponding to the Cordylodus proavus Zone (Dong 1985).

\section{Early Ordovician}

Tremadocian Stage. - Four conodont zones are recognized in Yichang Region and referred to the global Tremadocian Stage. The basal part of Tremadocian Stage includes the Cordylodus intermedius Zone, which is succeeded by the Rossodus manitouensis (= Acanthodus costatus- 'Acodus' oneotensis Zone of An et al. 1985, Dong 1985) Zone. The upper part includes Colaptoconus quadraplicatus and Paltodus 'deltifer' zones.

Cordylodus intermedius Zone. The base of the zone is at the FAD of the nominate species. It coincides with the base of the Ordovician System in China. The fauna includes Hirsutodontus simplex, Monocostodus sevierensis, Utahconus utahensis, Teridontus spp. and Semiacontiodus sp. The zone is recorded from the Nantsinkuan Formation.

Rossodus manitouensis Zone. The zone includes Acanthodus spp., Cordylodus angulatus, Monocostodus sevierensis, Semiacontiodus iowensis (= Acontiodus iowensis sensu An 1985), Variabiliconus bassleri and Rossodus manitouensis (= 'Acodus' oneotensus sensu An 1985).

Colaptoconus quadraplicatus Zone. The zone yields Colaptoconus quadraplicatus and Scolopodus barbatus.

'Drepanoistodus' paucicostatus Zone. This zone, established by An (1981), is characterized by the first appearence of 'Drepanoistodus' paucicostatus (= Drepanoistodus paucicostatus sensu An 1987).

Paltodus 'deltifer' Zone. The zone includes Paltodus 'deltifer', Drepanodus arcuatus, D. sp., Drepanoistodus sp. and Scandodus parallelus. The nominate species is not identical with $P$. deltifer sensu stricto; hence the species name is given in quotation marks.

Floian Stage. - The Floian Stage in the Yichang Region begins with the Serratognathus diversus Zone in the Hunghuayuan Formation and is succeeded by the informal Zone A, Oepikodus evae, Periodon flabellum and Microzarkodina russica zones in the Dawan Formation (An 1981, 1987; An et al. 1985; Wang et al. 2007, 2009). An (1987) distinguished a Baltoniodus communis Zone, which followed above the $S$. diversus Zone and below the O. evae Zone. Recent studies, however, suggest that Oepikodus communis is not present in China (Zhen et al. 2005). Instead, an informal and unnamed interval is distinguished here as Zone A.

Serratognathus diversus Zone. This biozone, named by An et al. (1983), is used here (see Zhen et al. 2009 for details on this zone); it ranges from the first appearence of the nominate species to the first appearence of Bergstroemognathus extensus (i.e. the base of zone A). An et al.
(1983) subdivided the zone into two informal (lower and upper) subzones, which can be distinguished by the first appearance of Juanognathus variabilis in the middle part of the Hunghuayuan Formation, but this subdivision is not used here. The biozone comprises a highly diverse assemblage of conodont species (el. appendix).

Zone A. As mentioned above, An et al. (1985) referred this interval to Baltoniodus communis Zone and it should largely correspond to the Prioniodus elegans Zone (An et al. 1985, Chen Xu et al. 1995). The interval is characterized by a highly diverse and complex conodont assemblage (el. appendix; Stouge \& Li, unpublished data). Bergstroemognathus extensus and Tropodus comptus (following T. australis; pars $=$ Triangulodus bifidus sensu Zhen et al., 2009) appear for the first time in this unnamed interval. The interval is recorded from the base of the Dawan Formation.

Oepikodus evae Zone. The zone comprises the interval from the first appearance of Oepikodus evae Zone to the first appearance to Periodon flabellum. The O. evae Zone includes a mixture of species known from Laurentia (e.g. Juanognathus, Reutterodus and Tropodus) and pandemic taxa (e.g. Gothodus, Lundodus, Periodon and Stolodus). The Oepikodus evae Zone is recorded from the lower half of member 1 of the Dawan Formation.

Periodon flabellum Zone. Although this interval is not formally defined, it is significant in the context of conodont diversity consideration. Here it represents the interval characterized by the first appearence of Periodon flabellum to the first appearance of Microzarkodina russica.

Microzarkodina russica Zone. It is youngest unit in the Floian Stage and it succeeds the Periodon flabellum Zone. This zone is present in the middle of the lower member of the Dawan Formation.

\section{Middle Ordovician}

Dapingian Stage. - The Dapingian Stage comprises three biozones, which are based on the Baltoniodus lineage (Wang et al. 2009), i.e. Baltoniodus triangularis, Baltoniodus navis and Baltoniodus norrlandicus zones (Fig. 2). The appearance of Baltoniodus triangularis is the base of the global Middle Ordovician Series and the Dapingian Stage. The conodont faunal succession in South China becomes nearly identical to that from Baltoscandia and the provincial differentiation between the two regions has almost disappeared (Stouge et al. 2009).

Baltoniodus triangularis Zone. The zone is defined by the FAD of Baltoniodus triangularis to the FAD of Baltoniodus navis (Wang et al. 2007, 2009). The zone is also characterized by the appearence of Microzarkodina flabellum, which is a direct successor of Microzarkodina russica. The fauna in this interval is very similar to the contemporaneous conodont fauna from the Baltoscandian region of northeastern Europe (Lindström et al. 1991, 


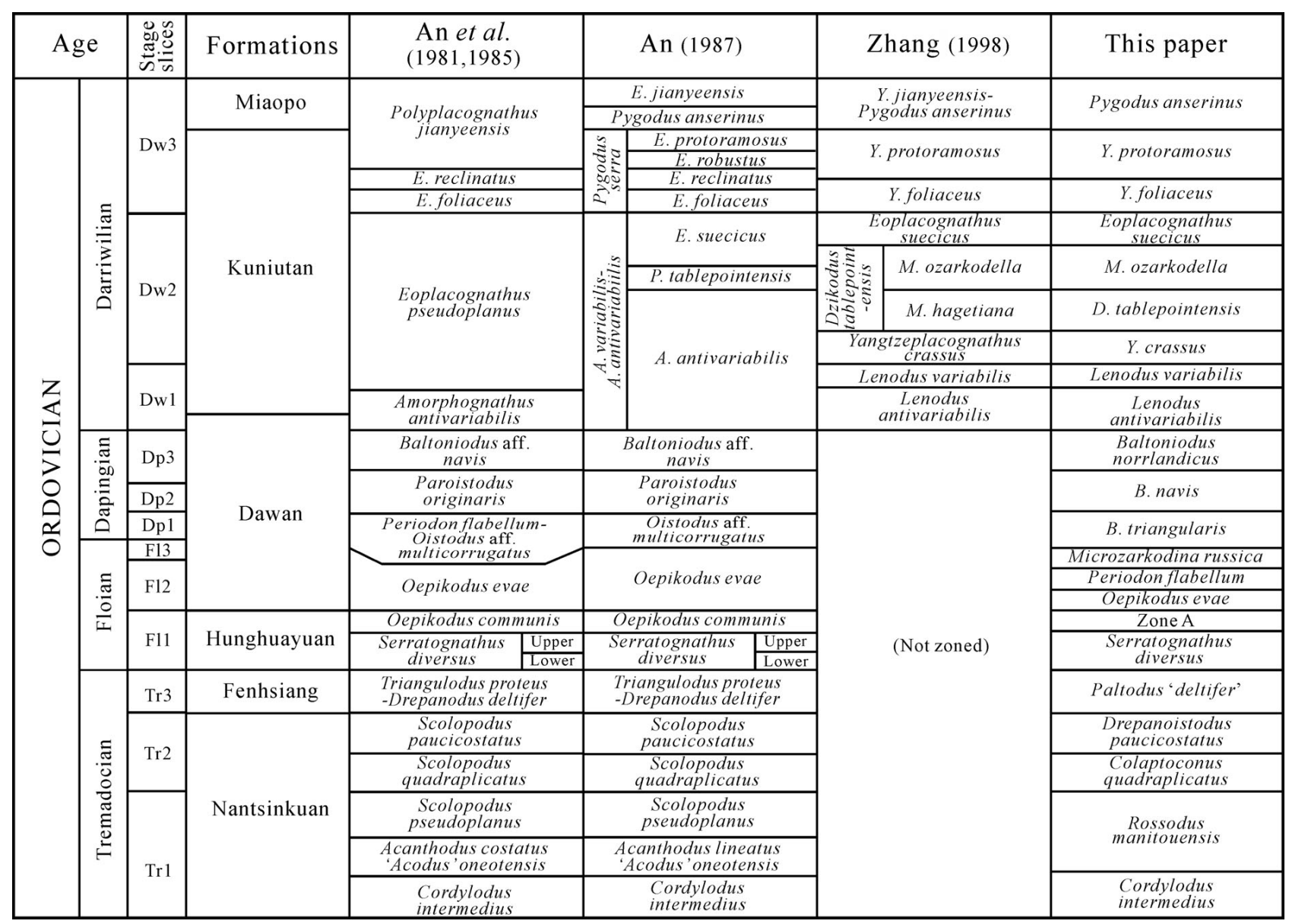

Figure 2. The correlation of Ordovician conodont zones in the Yichang area (after An 1987; An et al. 1981, 1985; Dong 1985; Zhang 1998) and those used as reference in this paper.

Bagnoli \& Stouge 1997, Stouge et al. 2009, Wang et al. 2009). The zone is recorded from the upper part of the lower unit of the Dawan Formation.

Baltoniodus navis Zone. The zone is distinguished by the appearance of Baltoniodus navis and extends to the appearence of Baltoniodus norrlandicus. The zone replaces the Oistodus aff. multicurrugatus Zone of Wang \& Bergström (1999) (Fig. 2). The zone is relatively low in diversity but often the fauna is dominated by Paroistodus originalis, Periodon aff. flabellum and Oistodus sp. A (sensu Bagnoli \& Stouge 1997).

Baltoniodus norrlandicus Zone. This zone is distinguished by the appearence of the nominate species. Previously, An $(1981,1987)$ named the zone Baltoniodus aff. navis Zone and Wang \& Bergström (1999) named it Baltoniodus norrlandicus-Microzarkodina parva Zone. The fauna is sparse and of low yield. The Baltoniodus norrlandicus Zone is recorded from the lower part of the upper member of the Dawan Formation and corresponds largely to the Undulograptus sinodentatus graptolite Zone.

Darriwilian Stage. - Many biozones are recognized in the
Darriwilian Stage (An 1987, Ni \& Li 1987, Wang \& Bergström 1995, Wang et al. 2007, Zhang 1998) (Fig. 2). The bases of most of the zones are defined as the level of first appearences of the nominate species. The Pygodus serra Zone is defined by the appearence of Pygodus serra for the north Atlantic region (Bergström 1971). In Yichang An (1987) and Ni \& Ji (1987) recorded the Pygodus serra Zone whereas Zhang (1998) proposed the Yangtzeplacognathus foliaceus and the Yangtzeplacognathus protoramosus zones but correlated these with the Pygodus serra Zone. Here the zones of Zhang (1998) are used as reference.

Lenodus antivariabilis Zone. The base of this zone is recognized by the first appearence of the nominate species (An 1987). The fauna includes Ansella longicuspica, Erraticodon balticus, and Scolopodus princeps. Histiodella altifrons is present in the zone. The zone is recorded from the upper part of the Dawan Formation and ranges into the lower member of the Kuniutan Formation. It corresponds to the Undulograptus austrodentatus Zone.

Lenodus variabilis Zone. This zone starts with the appearance of $L$. variabilis and is associated with Fahraeusodus marathonensis, Baltoniodus sp. 1 and Periodon 
macrodentatus. The associated fauna is diverse and several genera and species known from Laurentia become increasingly frequent. The zone is recorded from the lower member and ranges into the middle nodular bedded and silty member of the Kuniutan Formation.

Yangtzeplacognathus crassus Zone. This zone is defined by the total range of $Y$. crassus (i.e. Zhang 1998). The fauna is diverse and includes Baltoniodus clavatus, Microzarkodina hagetiana and Ansella jemtlandica. The zone is known from the uppermost part of the middle member and range into the upper member of the Kuniutan Formation.

Dzikodus 'tablepointensis' Zone. This zone ranges from the level where $Y$. crassus disappears to the base of Eoplacognathus suecicus Zone (Zhang 1998). The zone is subdivided into two subzones, i.e. Microzarkodina hagetiana and M. ozarkodella subzones (Zhang 1998). In the Yichang area a minor complication is that Dzikodus is only present together with Microzarkodina hagetiana, and the genus is represented by another species.

Microzarkodina ozarkodella Zone. The base of this subzone is distinguished by the first occurrence of Microzarkodina ozarkodella. The zone includes Baltoniodus medius, Histiodella kristinae and Periodon zgierzensis. The zone is recorded from the upper member of the Kuniutan Formation.

Eoplacognathus suecicus Zone. The zone is defined as the interval from the apparence of Eoplacognathus suecicus to the first appearance of Yangtzeplacognathus foliaceus (= part of Pygodus serra Zone). Associated species includes Periodon cf. aculeatus and Baltioniodus prevariabilis.

Yangtzeplacognathus foliacceus Zone. The base of this interval is defined by the first occurrence of Yangtzeplacognathus foliaceus. The zone is recorded from the Miaopo Formation (sensu Zhang 1998).

Yangtzeplacognathus protoramus Zone. The base of this zone is marked by the first appearance of the nominate species. The zone is recorded from the Miaopo Formation (Zhang 1998).

Pygodus anserinus Zone. The zone is recorded low in the Miaopo Formation and its base is stratigraphically below the appearance of Nemagraptus gracilis (= base of Sandbian Stage) in the Miaopo Formation.

\section{Conodont diversity in the Yichang Region}

\section{Methods}

Stages, stage slices (see Bergström et al. 2009) and conodont zones are used here as reference (Figs 2-4).

The available data on the occurrences of the conodonts from the Lower to the lower Upper Ordovician of the Yichang Region have been collected and used as basis for the study. The dataset comprises 68 conodont genera and 145 species (el. appendix). These data are a list of genera and species (Wang \& Wu 2007) and most species referred to well-established conodont multielement genera are included here.

The species are arranged as follows:

1. Names of species that have been recognized in the Yichang Region. Some species published in old papers are not included in the present list as many of them are, or are considered, potential junior synonyms.

2. Current generic attribution of species. Some generic assignments are changed from the original assignment, and more are expected to change for several species in the interval. Some taxa are informally named 'Genus' awaiting a revision of the fauna.

3. Stratigraphic distribution of the species in the Yichang Region according to the current global stratigraphic division of the Ordovician (Bergström et al. 2009) and regional biozones (Fig. 2).

\section{Stratigraphy and duration of the stages}

The boundaries of the stages used here as reference are the international or global stages for the Ordovician System (Gradstein et al. 2004, Cooper \& Sadler 2004, Webby et al. 2004, Bergström et al. 2009, Ogg et al. 2008). This is, however, not a simple process and several problems appeared.

1. One problem is that the duration of the specific global stages is not the same (Figs 3,4). This can have influence on the number of species and thus favour a high diversity level for the longer stages as these are likely to be comprised by more genera and species than the short or shorter stages.

2. Another problem is that the quality of generic and species identifications varies because especially the old conodont systematic approach - i.e. the form-element taxonomy - has been used in the older literature for Central China. Several Tremadocian conodont genera have recently been revised (e.g. Ji \& Barnes 1994, Landing 1993, Landing et al. 2003) and some Floian genera are still in the progress of revision (Landing \& Westrop 2006; Zhen et al. 2003, 2006a, b; Stouge \& Li in prep. and Wu \& Stouge in prep.). The conodont fauna from the Dapingian Stage is also in the process of revision (Wang et al. 2003, 2009; Stouge et al. 2007). Zhang (1998), however, provided a modern taxonomy for the Kuniutan Formation of the Darriwilian Stage and this interval appears to be taxonomically stable and only minor revision is needed.

3. The different intensity of research from one stage to another stage is an additional problem and provides a skewed image of the diversity pattern through time. Conodonts from one formation/zone have received more attention than conodonts from another formation/zone; 


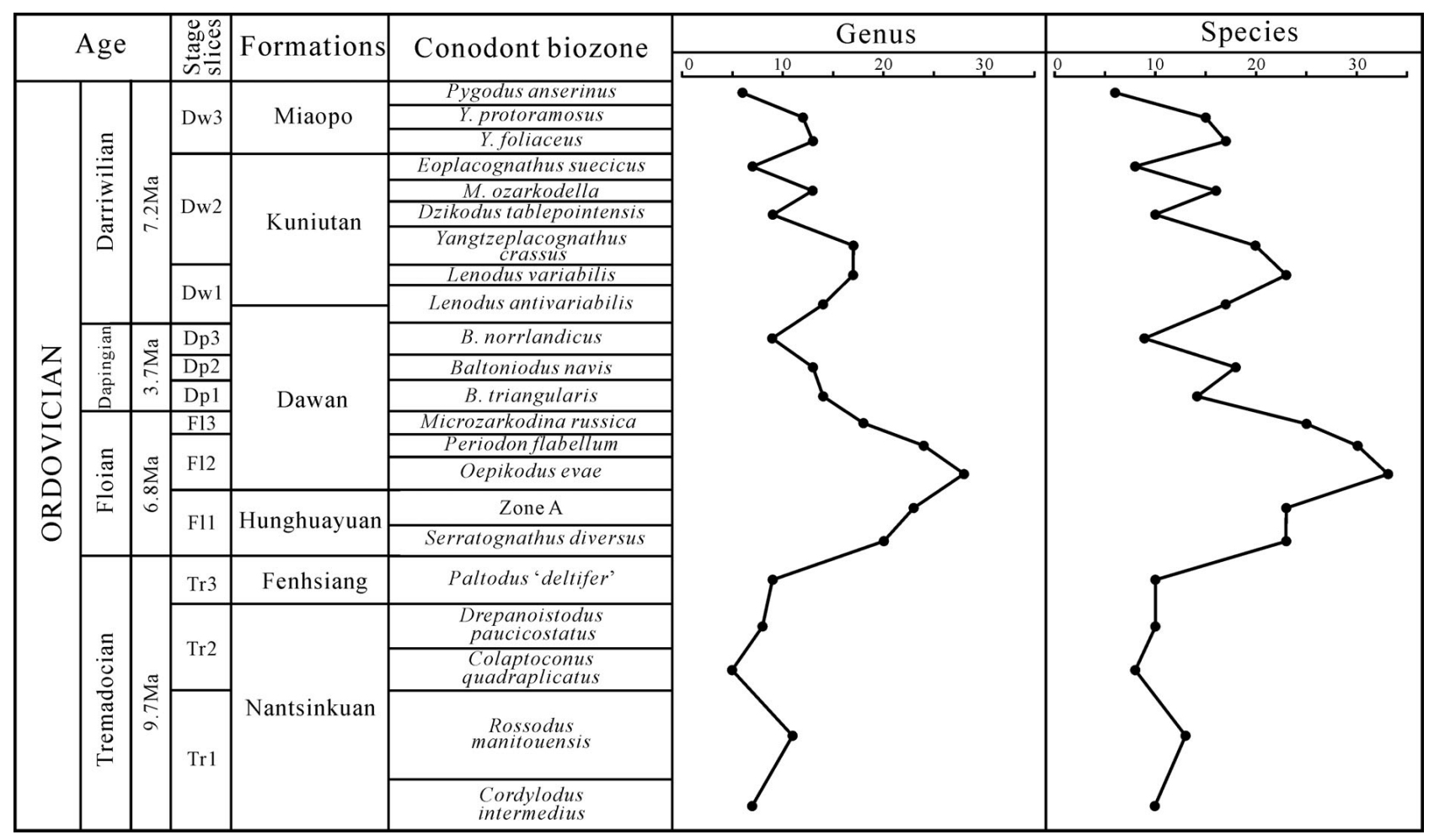

Figure 3. Changes in number of conodont genera and species in the Lower to Mid Ordovician at Yichang Region, Hubei Province.

especially global series and stage boundary intervals have been investigated in great detail. This may give the impression of important changes in biodiversity across the boundaries, when in fact it reflects the differences in intensity of study.

4. The number of specimens and samples from different stages and sites is not always available due to the lack of data in the older literature. For example, it has been common to provide a fauna list without indication of the number of specimens involved for each species.

5. The disappearence of a taxon or taxa - especially species - from a region and its/their return to the region in another and younger stage ('false Lazarus species'). This is especially typical in a regional study and a lower diversity level or a higher extinction rate may be reached for an interval where the species has migrated away and when compared to the global curve. In this study only the presence are included in Figs 3 and 4.

\section{Analysis}

The analysis presented here uses the 'mean standing diversity (MSD) over a specified interval' (Cooper 2004, p. 52). The procedure is the same as described by Cooper (2004) and Total diversity $\left(d_{t o t}\right)$ are presented. The normalized diversity measure $\left(d_{\text {norm }}\right)$ sensu Cooper (2004) is not used here, whereas the 'balanced total diversity measure' $\left(d_{b t d}\right)$ and the rules for counting species are following the guidelines of Paris et al. (2004, p. 296).

The origination speed $\left(o_{d}\right)$ is calculated for each stage slice; it is an expression for the number of FADs per stage slice or zones and is calculated by dividing the number of originations by the total number of species present in the stage slice. The $\left(o_{d i}\right)$ is the pace of species origin and is calculated by dividing the origination by the duration of the corresponding stage slice expressed in m.y. The extinction speed $\left(e_{d}\right)$ is calculated for each stage slice i.e. the number of extinctions is divided by the total number of species recorded in the stage slice or zone. The $\left(e_{d i}\right)$ is speed of species extinction expressed in m.y.; it is calculated by dividing the $\left(e_{d}\right)$ with the duration of the stage slice or zone expressed in m.y.

The turnover (TR) ratio has been calculated by $(O-E) / \mathrm{BTD}$ for each stage slice or zone.

\section{Results}

The number of genera and species of the conodonts (el. appendix) or total diversity $\left(d_{t o t}\right)$, balanced total diversity $\left(d_{b t d}\right)$, the origination $\left(o_{d}\right)$, the speed of species origination $\left(o_{d i}\right)$, the extinction $e_{d}$, the rate of extinction $\left(e_{d i}\right)$ and turnover ratio (TR) are plotted against stages and stage slices in Figs 3 and 4. The data suggests cyclic or recurrent patterns of diversity, which is considered characteristic for the investigated time interval. 


\section{Tremadocian Stage}

Taxonomic diversity. - In first cycle the $d_{\text {tot }}$ shows average values of 10 and peaks in the lower Tremadocian, where a maximum of $d_{\text {tot }} 13$ species and 11 genera is recorded from the Rossodus manitouensis Zone (= stage slice $\operatorname{Tr} 1$ ). The second cycle recorded with a maximum in diversity is from the 'Drepanoistodus' paucicostatus and Paltodus 'deltifer' zones (Upper Tremadocian); here a maximum of 10 species is present. This peak however is relatively weak or low and as a whole the late Tremadocian Stage shows low to moderate diversity.

Turnover. - The TR curve shows a gradual positive trend in stage slice $\operatorname{Tr} 1$ and peaks in stage slice $\operatorname{Tr} 2$. The $d_{\text {tot }}$ peak in stage slice $\operatorname{Tr} 1$ is not matched by the TR curve.

The origination rates matched respectively the $d_{t o t}$ and TR curves, where the origination rate $\left(o_{d}\right)$ is nearly similar to the $d_{t o t}$ curve and the $o_{d i}$ curve matches the TR curve, but both curves show a negative rate in stage slice $\operatorname{Tr} 3$, which highlights a 'Low diversity interval' in South China.

\section{Floian Stage}

Taxonomic diversity. - The Floian Stage records one large diversity cycle beginning with 23 species and 20 genera in the Serratognathus diversus Zone from the Hunghuayuan Formation and in Zone A from near the top of the Hunghuayuan Formation and base of the Dawan Formation (Fig. 3). The $d_{t o t}$ and $d_{b t d}$ curves match each other and show average values between 25 and 19. The maximum diversity event starting in stage slice Fl 1 and culminating in stage slice Fl 2 is clearly demonstrated and a maximum in species richness is recorded in the Oepikodus evae Zone, where 33 species are present in the lower member of the Dawan Formation (Figs 3, 4, el. appendix). This maximum of diversity in the Floian Stage is remarkable because the number of species is the highest total within the investigated time interval. The number of species decreases upwards and falls to 25 species in the Microzarkodina russica Zone in the middle part of the lower unit of the Dawan Formation.

Turnover. - The TR curve does not demonstrate that major changes in diversity occurred in the Floian Stage and the maximum peak in diversity is not or barely reflected in the TR curve. The two origination curves jump from the low value of stage slice $\operatorname{Tr} 3$ to high values in stage slice Fl 1 and then in stage slice Fl 3 return to the same low level as seen in stage slice $\operatorname{Tr} 3$. The $e_{d i}$ and $e_{d}$ curves are stable in the Floian Stage but demonstrate a remarkable positive peak in stage slice Fl 3. The extinction curves suggest that a (regional) conodont extinction event occurred during stage slice Fl 3 (Fig. 4).

\section{Dapingian Stage}

Taxonomic diversity. - The Dapingian Stage comprises one cycle of diversity. The $d_{t o t}$ and $d_{b t d}$ curves start with 14 genera and species in the stage slice Dp 1 (=Baltoniodus triangularis Zone), a maximum in diversity with a total of 18 species in stage slice Dp 2 (= the B. navis Zone) followed by a drop in diversity to 9 species in the following stage slice Dp 3 (= Baltoniodus norrlandicus Zone) (el. appendix, Figs 3, 4). The decrease in diversity in the stage slice Dp 3 of the Dapingian Stage is associated with an increase in dominance of few genera such as Oistodus, Paroistodus and Periodon.

Turnover. - The TR curve increases to low positive values in the stage slice Dp 1 only to drop to a negative value along with the peak of $d_{t o l}$ and $d_{b t d}$ in stage slice Dp 2. A gradual raise of the TR curve initiates in stage slice Dp 3 and this trend continues into the stage slice Dw 1.

The origination curves, $o_{d}$ and $o_{d i}$, display a nearly identical pattern in the Dapingian and have a similar appearance as to the TR curve i.e. with a drop to low values in stage slice Dp 2. The extinction i.e. $e_{d}$ and $e_{d i}$ curves drop to low values in stage slice Dp 1 and the curves are developed nearly as a mirror picture of the TR curve and reach values of 0.4 to 0.6 in stage slice Dp 2 .

\section{Darriwilian Stage}

Taxonomic diversity. - The species diversity in the Darriwilian Stage begins with 17 species in the stage slice Dw 1 (= Lenodus antivariabilis Zone) and culminates with 23 species in the Lenodus variabilis Zone of upper stage slice Dw 1 (Fig. 4). Higher in the Darriwilian Stage, the number of species gradually decreases and reaches a low of 8 species in the Eoplacognathus suecicus Zone at the top of stage slice Dw 2 (Fig. 4). In stage slice Dw 3 the conodont fauna of the Yangtzeplacognathus foliaceus Zone has a maximum of 17 species, but this number falls gradually to a low of 6 species in the Pygodus anserinus Zone at the top of the stage slice Dw 3.

Turnover. - The gradual increase that started in stage slice Dp 3 culminates in stage slice Dw 1 and decreases in stage slice Dw 2. Another increase occurs in stage slice Dw 3 but decreases to the lowest value recorded in the succession investigated here in stage slice Dw 3.

The origination rates follow the same pattern as the TR curve for the stage slices Dw 1 and Dw 2. The short peak displayed in stage slice Dw 3 matches the single positive peak seen in the TR curve. The extinction curves show the opposite trends to the TR curve and the origination rate curves and reach the highest peak recorded in this investigation in stage slice Dw 3 (Fig. 4). 


\section{Diversity changes across system, series and stage boundaries}

The conodont diversity is low in Late Cambrian where only 7 species and 5 genera are known in the region (electronical appendix). In the early Tremadocian the number of species starts with 10 and 7 genera suggesting that an increase in diversity occurred across the Cambrian/Ordovician systemic boundary (Fig. 3). The Tremadocian/Floian Stage boundary is characterized by a low diversity fauna below the boundary, which is followed by a very rapid increase above the base of the Floian Stage. The middle Ordovician Series boundary, or the base of the Dapingian Stage, is preceded by a relatively high minimum in the number of species near or at the top of the Floian Stage (Microzarkodina russica Zone). This 'minimum' is succeeded by a low value of 14 species at the base of the Dapingian Stage. The same transition i.e. from the top of the Floian Stage to Dapingian Stage is associated with a high extinction rate (Fig. 4, $e_{d i}$ ). The Dapingian/Darriwilian boundary represents a significant increase from stage slice Dp 3 with the minima of 9 species presenting at the top of the Dapingian and immediately followed by 17 species in stage slice Dw 1 of the Darriwilian Stage.

\section{Comparison with diversity trends of other fossil groups}

In South China, the Ordovician record of acritarchs starts in the Tremadocian Stage, where a lower assemblage of nine species has been recorded by Brocke \& Li (1999), Brocke et al. (2000) and Li et al. (2004, 2007). Similar to conodonts the first assemblage is present in the Rossodus manitouensis conodont Zone (stage slice Tr 2); the second acritarch assemblage from the late Tremadoc has relatively low diversity (seven species). A continuous increase in acritarch diversity during Floian Stage has been noted and it reached 23 species in the Serratognathus diversus Zone (stage slice Fl 1) followed by 21 species in the Oepikodus evae Zone (stage slice Fl 2) (Brocke 1999; Brocke \& Li 1999; Li et al. 2002, 2007). The Dapingian Stage, however, represents the highest diversification (49 to 50 species) in the upper part of the lower member of the Dawan Formation (Baltoniodus triangularis Zone, stage slice Da 1) (Brocke et al. 2000). The acritarchs are low diverse to nearly absent in the red limestone of the middle member of the Dawan Formation (Baltoniodus navis Zone, stage slice Da 2), a lithology that probably reflects a low preservation potential for acritarchs rather than a true picture of the acritarch diversity. In the Darriwilian the acritarchs were moderately diverse (32) species in the Lenodus antivariabilis Zone (pars stage slice Dw 1) and the diversity increases to
42 species in the Lenodus variabilis Zone. Li et al. (2002) related the general pattern of diversity of the acritarchs from the Tremadocian to the Darriwilian to sea-level changes whereas lateral distribution of different assemblages depended on local palaeoecological factors such as distance from the coast and the water depth (Li \& Yan 2006, Li et al. 2004a).

The species diversification of acritarchs is to a certain degree comparable to that shown by the conodonts i.e. both have coeval highly to relatively highly diverse assemblages in the Floian and Darriwilian stages in the region. A major difference is the maximum peak recorded for acritarchs in the Dapingian Stage with 49 or 50 species (Brocke et al. 2000, Li et al. 2004) whereas the coeval conodont diversification is moderately low in the Yichang Region in this time interval.

Based on the study of brachiopods from the Upper Yangtze Platform, the brachiopod radiated much earlier than other marine animals; they had their first diversity peak in the late Early Ordovician Didymograptellus eobifidus Biozone (stage slice Fl 2, Oepikodus evae and Periodon flabellum zones) and a second but minor maximum in the Undulograptus austrodentatus Zone (stage slice Dw 1). The first was manifested by strong ecological differentiation of benthic communities, and was formed in complex benthic environments (Zhan \& Harper 2006, Zhan \& Rong 2006). The first radiation of the brachiopods in South China was earlier than that of the great Ordovician biodiversification (Webby 2004) and brachiopod macroevolution (Harper et al. 2004), i.e. about 3-4 graptolite biozones or approximately 6 to $8 \mathrm{Ma}$ (Zhan \& Rong 2006). This maximum peak in the Floian, however, corresponds well with both the high acritarch and the maximal conodont diversification in the region.

In the Yichang Region, the trilobites have a diversity maximum at the top of the Dapingian Stage (stage slice Dp 3) although a second maximum is indicated but not documented for the stage slice Dp 1 (Turvey 2007). The highest diversity level is observed in the AsaphidRaphiophorid Association at the Chenjiahe section (18 species) (Turvey \& Zhou 2002) where it is recorded from unit 3 of the Dawan Formation. The AsaphidRaphiophorid Association represents an intermediate water depth. The reasons for this diversification of trilobites could not be determined with certainty (Turvey 2007).

This pattern is opposite to the conodonts where a miminum in diversity has been recorded in the upper unit of the Dawan Formation (= Baltoniodus norrlandicus Zone, stage slice Dp 3). Hence it appears that the trilobites peaked in diversity later than all other groups, i.e. in the Dapingian Stage (Baltoniodus norrlandicus conodont Zone, Undulograptus sinodentatus Zone; stage slice Da 3) in the region. 


\section{Conodont diversity and facies changes}

The change in diversification for conodonts appears to follow lithology/facies, where shallow and warm water nearshore carbonates are relative low in diversity, but is later followed by higher to high diversification in offshore carbonates. In contrast, silt, shale and shale in general show respectively low diversity or have no conodonts. Especially stage slice Dp 3 i.e. Baltoniodus norrlandicus Zone from the upper unit of the Dawan Formation is an example on low diversity conodont faunas associated with predominance of silt to shale facies.

This lithological/facies pattern is not comparable with the pattern of diversity displayed by acritarchs, brachiopods, and trilobites, where these fossil groups reach their maximum diversity in marly and shale-rich intervals ( $\mathrm{Li}$ et al. 2004a, Zhan \& Harper 2006, Turvey 2005).

\section{Conodont diversity and sea-level change}

The association of variation in floral and faunal diversity with lithofacies suggests that the floral and faunal diversity changes in the region were related to sea-level changes $(\mathrm{Li}$ et al. 2004, 2007; Wu et al. 2010). However, the fossil groups did not have the same preference in habitat and hence show diachronous maxima for the peak diversity in the Yichang Region.

The peak in species diversity for conodonts from Zone A and $O$. evae Zone (= stage slice Fl 2 of the Floian Stage) is also reported from the coeval Zitai Formation in eastern China (Wu et al. 2010). Stouge et al. (2009) briefly compared the species diversity curves for Baltica and South China, and found that the maximum conodont species diversity in the Floian Stage is comparable and coeval for both regions; in turn, it is also in line with the global trend presented by Albanesi \& Bergström (2004). The main difference between Baltica and South China diversities is that the total number of species is lower in Baltica than at Yichang in South China. This high peak in diversity corresponds directly to the prominent global evae transgression (Barnes 2004, Nielsen 2004), which also reached onto the South China Platform.

\section{The Floian diversification: sea cooling and change of ocean currents?}

Trotter et al. (2008) found that a general cooling of the ocean occurred in the Dapingian Stage. Lehnert et al. (2007) presented a $\delta^{18} \mathrm{O}$ temperature curve, based on apatite from conodonts, for the Yichang area, South China. The curve shows a cooling trend from warm waters in the Late Cambrian and towards the end of the Early Ordovician, where fluctuation between warm and cool temperature prevailed. The Dapingian Stage was generally cool and the temperature returned to temperate in the Darriwilian. The authors related the cooling trend to changes in the watermass, perhaps caused by plate tectonics, which in turn caused temporary change of the oceanic current pattern (Christiansen \& Stouge 1999, Barnes 2004, Stouge et al. 2005).

It is also clear from the conodont fauna in the succession at Yichang that a cooling trend occurred from the Tremadoc, through Floian and into the Dapingian stages. The conodont fauna association from the early Tremadocian is characteristic for warm and shallow, and also higher salinity, water, typical of the North American Midcontinent realm. The second or late Tremadocian conodont faunal association is comparable with the 'Low Diversity Interval' of Ross et al. (1997) and the Macerodus dianae interval, which occurs in warm, peritidal environments or shallow water subtidal settings. The Serratognathus conodont fauna is associated with receptaculitid mounds and oncoids, and it is in general a shallow warm but open water association and this is supported by its occurrence in the South China conodont province. Later, the fauna becomes relatively temperate character and the Oepikodus-Juanognathus-Reutterodus association suggests a change from shallow to deeper subtidal water environments. The appearance of Baltoniodus and its allies in the late Floian and Dapingian stages represent the main cooling interval in the region (Lehnert et al. 2007a) and the appearence in the Yichang area of this temperate to cool water conodont faunal association - so characteristic for Baltica - may well be related to the general cooling of the water mass proposed by Trotter et al. (2008). This cooling may also be responsible for the high extinction value recorded in stage slice Fl 3 (Fig. 4) as the warmer conodont faunal elements disappeared from the region.

The change in ocean currents may also explain the migration of cooler types of conodont species towards South China (Stouge et al. 2005), which resulted in a nearly disappearance of provincial boundaries between Baltica and South China (Stouge et al. 2009).

\section{Darriwilian diversification: extraterrestrial cause of the raised biodiversity?}

An exception to the close association between conodont diversity and lithofacies in the study region, which was mentioned above, is in the middle member of the Kuniutan Formation (stage slice Dw 1 = Lenodus variabilis Zone), where a second high maximum in conodont diversification is recorded (Figs 3, 4). The lithology and facies of the second member in the Kuniutan Formation - which is dominated by silt, shale and nodular limestone - is not favourable for conodont yield and/or high diversity association. Thus, another cause may be the explanation for the high diversity. Schmitz 


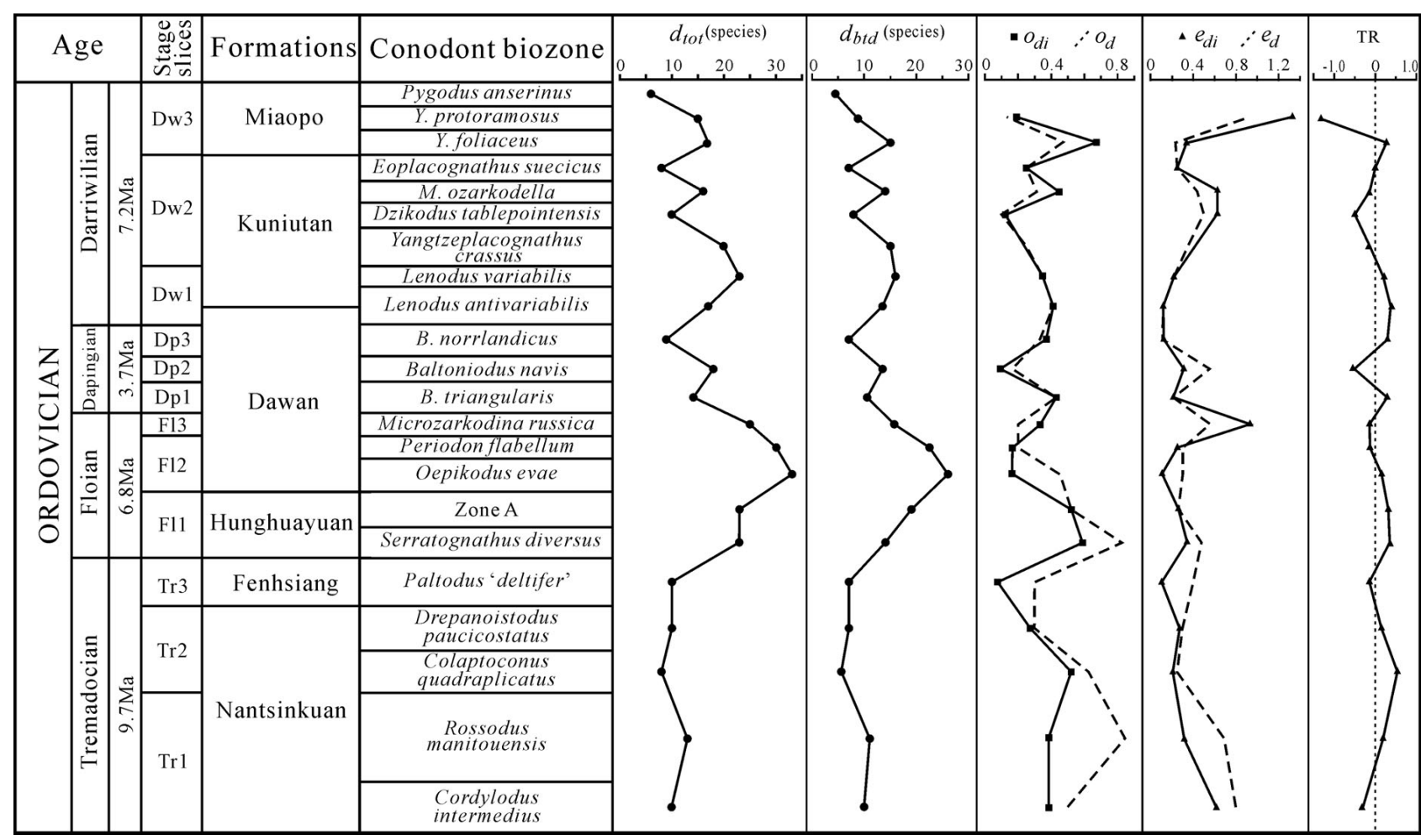

Figure 4. Biodiversity of Lower and Middle Ordovician conodont species from Yichang Region, Hubei Province, Central China. $d_{b t d}=$ balanced total diversity $o_{d}=$ species origination rate; $o_{d i}=$ species origination rate per m.y.; $e_{d}=$ species extinction rate; $e_{d i}=$ species extinction rate per m.y.; TR $=$ species turnover rate.

et al. (2008) recorded a high concentration of extraterrestrial chromites, representing meteorites, from this interval in the Yichang area. The cromites were interpreted to be the product of the largest disruption in the asteroid belt and considered possible triggers for the Middle Ordovician biodiversification of shelled invertebrates (Schmitz et al. 2008).

The conodonts do display an increase in diversity in the Darriwilian. Hence, the unexpected and high diversification rise for conodonts in Darriwilian (Fig. 4) may have been effected by the same meteorite impact that accelerated the biodiversification process for some invertebrates according to Schmitz et al. (2008).

\section{Conclusion}

The overall pattern, or first order in conodont species diversity, from the Lower and Middle Ordovician is twofold. A general increase in diversity is recorded in the Early Ordovician. This Early Ordovician progressive increase in species richness reaches a maximum of diversity high in the second stage slice of the Floian Stage. Here 33 species are recorded which represent the highest number of conodont species obtained in the Ordovician in the Yichang Region. The number in species presented here for the Floian Stage is a conservative estimate and will probably increase when the fauna from this interval is completely described (Stouge \& Li in preparation).

A second order diversity increase in species richness is recorded from the Middle Ordovician. The species richness begins to increase starting from the base of the Darriwilian Stage and it reaches a high level of 23 species in the Lenodus variabilis Zone.

The diversity pattern shows low values in diversity at, or just after, a series or stage boundary i.e. the maximum diversities are recorded within the series and stages and not at their boundaries or across series and stage boundaries.

The highest conodont diversification in the Early Ordovician shows a parallel to diversity maxima for both acritarchs and brachiopods, which display a similar high peak in the Early Ordovician (Li et al. 2004a, 2007; Zhan \& Harper 2006). Whether this means that phytoplankton diversity is a prelude to the diversities of other groups (Lehnert et al. 2007b) still remains to be investigated.

Distribution of the conodont diversity depends also on lithofacies and shows a gradient from onshore-offshore during the Early Ordovician. The low diversity recorded in the Tremadocian Stage is derived from shallow water carbonates and minor shales. The following higher to high peak in the Floian Stage reflects change from open shallow marine carbonates to offshore interbedded carbonate-shale facies. The mix of cooler water taxa with 
warmer water taxa may result in a high degree of diversity in the region.

A cooling trend in the water mass may be related to the change in conodont diversification and caused a regional extinction peak, which is highlighted by the extinction curve $e_{d} / e_{d i}$ (Fig. 4) in stage slice Fl 3 in the Hubei region. This event may be a response to sea-level changes.

The extinction curve $e_{d i}$ shows a second (regional?) extinction peak in stage slice Dw 3 , but the cause to this possible extinction event has not been detected in this paper.

\section{Acknowledgements}

This project was funded by the Chinese Academy of Sciences (KZCX2-YW-Q05-01), and the National Natural Science Foundation of China (40825006), the Ministry of Science and Technology of China (2006CB806402) and the Carlsberg Foundation, Denmark. We are grateful to the journal referees S.M. Bergström and J. Dzik for their constructive comments and corrections, which greatly improved the manuscript. This paper is a contribution to the International Geological Correlation Program (IGCP) Project No. 503: Ordovician Palaeogeography and Palaeoclimate.

\section{References}

Adachi, N., EzaKi, Y., LiU, J. \& CAO, J. 2009. Early Ordovician reef construction in Anhui Province, South China: A geobiological transition from microbial- to metazoan-dominant reefs. Sedimentary Geology 220, 1-11.

DOI 10.1016/j.sedgeo.2009.05.012

Albanesi, G.L. \& BergströM, S.M. 2004. Conodonts: Lower to Middle Ordovician Record, 312-326. In WebBy, B.D., PARIS, F., Droser, M.L. \& Percival, I.G. (eds) The Great Ordovician Biodiversification Event. 484 pp. Columbia University Press, New York.

AN, T.X. 1981. Recent progress in Cambrian and Ordovician conodont biostratigraphy of China. Geological Society of America Special Papers 187, 209-226.

An, T.X. 1987. Early Paleozoic conodonts from South China. 238 pp. Peking University Publishing House, Beijing. [in Chinese with English abstract]

An, T.X., Du, G.Q. \& GaO, Q.Q. 1985. Study on the Ordovician conodonts from Hubei. 64 pp. Geological Publishing House, Beijing. [in Chinese with English abstract]

An, T.X., Du, G.X., GaO, Q.Q., Chen, Q.B. \& LI, W.T. 1981. Ordovician conodont biostratigraphy of the Huanghuachang area of Yichang, Hubei, 105-113. In Micropalaeontological SoCIETY OF ChINA (ed.) Selected Papers of the First Symposium. Science Press, Beijing. [in Chinese]

An, T.X., Zhang, F., XIANG, W.D., Zhang, Y.Q., Xu, W.H., Zhang, H.J., Jiang, D.B., Yang, C.S., Lin, L.D., Cui, Z.T. \& YANG, X.C. 1983. The conodonts in North China and adjacent regions. 223 pp. Science Press, Beijing. [in Chinese with English abstract]

Bagnoli, G. \& Stouge, S. 1997. Lower Ordovician (Billingenian-Kunda) conodont zonation and provinces based on sec- tions from Horns Udde, North Öland, Sweden. Bolletino Società Paleontogica Italiana 35, 109-163.

BARNeS, C.R. 2004. Ordovician Oceans and Climate, 72-76. In Webby, B.D., Paris, F., Droser, M.L. \& Percival, I.G. (eds) The Great Ordovician Biodiversification Event. 484 pp. Columbia University Press, New York.

BergströM, S.M. 1971. Conodont biostratigraphy of the Middle and Upper Ordovician of Europe and Eastern North America. Geological Society of America Memoir 127, 83-161.

Bergström, S.M., Chen, X., GutiérRez-Marco, J.C. \& Dronov, A. 2009. The new chronostratigraphic classification of the Ordovician System and its relations to major regional series and stages and to $\delta^{13} \mathrm{C}$ chemostratigraphy. Lethaia $42,97-107$. DOI 10.1111/j.1502-3931.2008.00136.x

BRocke, R. 1997. First results of Tremadoc to lower Arenig acritarchs from the Yangtze Platform, South China. In FATKA, O. \& Servais, T. (eds) Acritarcha in Praha. Acta Universitatis Carolinae, Geologica 40(3-4), 337-356.

Brocke, R. \& Li, J. 1999. Preliminary results on upper 'Arenigian' to lower 'Llanvirnian' acritarchs from South China. Acta Universitatis Carolinae, Geologica 43, 259-261.

Brocke, R., LI, J. \& WANG, Y. 2000. Upper Arenigian to lower Llanvirnian acritarch assemblages from South China: a preliminary evaluation. Review of Palaeobotany and Palynology 113, 27-40. DOI 10.1016/S0034-6667(00)00050-6

Chen, X., Rong, J.Y., WAng, X.F., WANG, Z.H., Zhang, Y.D. \& ZHAN, R.B. 1995. Correlation of Ordovician Rocks of China. International Union of Geological Sciences Publication 31, $1-104$.

Christiansen, J.L. \& Stouge, S. 1999. Oceanic circulation as an element in palaeogeographical reconstructions: the Arenig (early Ordovician) as an example. Terra Nova 11, 73-78. DOI 10.1046/j.1365-3121.1999.00229.x

Cocks, L.R.M. \& TorsviK, T.H. 2004. Major Terranes in the Ordovician, 61-67. In Webby, B.D., PARIS, F., Droser, M.L. \& Percival, I.G. (eds) The Great Ordovician Biodiversification Event. 484 pp. Columbia University Press, New York.

Cooper, R.A. 2004. Measures of Diversity, 52-57. In WebBy, B.D., PARIs, F., Droser, M.L. \& Percival, I.G. (eds) The Great Ordovician Biodiversification Event. 484 pp. Columbia University Press, New York.

CoOPer, R.A. \& SAdLer, P.M. 2004. The Ordovician System, 165-187. In Gradstein, F.M., OGG, J.G. \& SMith, A.G. (eds) A Geologic Time Scale 2004. Cambridge University Press, Cambridge.

DonG, X.P. 1985. Conodont-based Cambrian-Ordovician boundary at Huanghuachang of Yichang, Hubei, 383-412. In NANJING Institute of Geology and Palaeontology, Academia Sinica (ed.) Stratigraphy and Palaeontology of Systemic Boundaries in China, Cambrian-Ordovician Boundaries (2). Anhui Science and Technology Publishing House, Hefei.

Gradstein, F.M., OGG, J.G. \& Smith, A.G. 2004. A Geologic Time Scale 2004. 589 pp. Cambridge University Press, Cambridge.

Harper, D.A.T., Cocks, L.R.M., Popov, L.E., Sheehan, P.M., Bassett, M.G., Copper, P., Holmer, L.E., Jin, J.S. \& RonG, J.Y. 2004. Brachiopods, 157-178. In WebBy, B.D., PARIs, F., Droser, M.L. \& Percival, I.G. (eds) The Great Ordovician Biodiversification Event. 484 pp. Columbia University Press, New York.

JAANUSSON, V. 1961. Discontinuity surfaces in limestones. Bulletin of the Geological Institute, of the University of Uppsala 40, 221-241. 
Ji, Z.L. \& BARNES, C.R. 1994. Lower Ordovician conodonts of the St. George Group, Port au Port Peninsula, western Newfoundland, Canada. Palaeontographica Canadiana 11, 1-149.

LANDING, E. 1993. Cambrian-Ordovician boundary in the Taconic Allochthon, Eastern New York, and its interregional correlation. Journal of Paleontology 67(1), 1-19.

LANDING, E. \& WESTROP, S.R. 2006. Early Ordovician faunas, stratigraphy, and sea-level history of the middle Beekmantown Group, Northeastern New York. Journal of Paleontology 80(5), 958-980. DOI 10.1666/0022-3360(2006)80[958:LOFSAS]2.0.CO;2

Landing, E., Westrop, S.R. \& VAn Aller Hernick, L. 2003. Uppermost Cambrian Lower Ordovician Faunas and Laurentian Platform Sequence Stratigraphy, Eastern New York and Vermont. Journal of Paleontology 77(1), 78-98. DOI 10.1666/0022-3360(2003)077<0078:UCLOFA>2.0.CO;2

Lehnert, O., Stouge, S., JoAchimski, M. \& Buggisch, W. 2007a. $\delta^{18}$ record from conodont apatite across the Lower-Middle Ordovician boundary on the Yangtze Platform (Western Hubei, South China). Acta Palaeontologica Sinica 46 (Suppl.), 256-261.

Lehnert, O., Vecoli, M., Servais, T. \& Nützel, A. 2007b. Did plankton evolution trigger the Ordovician diversification? Acta Paleontologica Sinica 46 (Suppl.), 262-268.

Li, J., BRocke, R. \& SERVAis, T. 2002. The acritarchs of the South Chinese Azygograptus suecicus graptolite Biozone and their bearing on the definition of the Lower-Middle Ordovician boundary. Comptes Rendus Palevol 1(2), 75-81.

DOI 10.1016/S1631-0683(02)00016-7

Li, J., Servais, T., Yan, K \& Zhu, H.C. 2004a. A nearshore-offshore trend in acritarch distribution from the Early-Middle Ordovician of the Yangtze Platform, South China. Review of Palaeobotany and Palynology 130, 141-161.

DOI 10.1016/j.revpalbo.2003.12.005

Li, J., Servais, T., Yan, K. \& Su, W. 2007. Microphytoplankton diversity curves of the Chinese Ordovician. Bulletin de la Société Géologique de France 178(5), 399-409. DOI 10.2113/gssgfbull.178.5.399

LI, Z.H., WANG, Z.H., WANG, X.F., Chen, X.H., WANG, C.S. \& QI, Y.P. 2004b. Conodonts across the Lower-Middle Ordovician boundary in the Huanghuachang section of Yichang, Hubei. Acta Palaeontologica Sinica 43(1), 14-31. [in Chinese with English abstract]

Li, J. \& YAN, K. 2006. Radiation of Early-Middle Ordovician acritarchs in South China, 313-333. In RoNG, J.Y., FANG, Z.J., Zhou, Z.H., Zhan, R.B., Wang, X.D. \& Yuan, X.L. (eds) Originations, Radiations, Biodiversity Changes - Evidences from the Chinese Fossil Record. Science Press, Beijing. [in Chinese with English abstract]

LindströM, M., CHEN, J.Y. \& ZhANG, J.M. 1991. Section at Daping reveals Sino-Baltoscandian parallelism facies in the Ordovician. Geologiska Föreningens $i$ Stockholm Förhandlingar 113, 189-205.

LÖFGREN, A. \& TOLMAChEVA, T. 2008. Morphology, evolution and stratigraphic distribution in the Middle Ordovician conodont genus Microzarkodina. Earth and Environmental Science Transactions of the Royal Society of Edinburgh 99, 27-48. DOI 10.1017/S1755691008007056

Metcalfe, I. 1998. Palaeozoic and Mesozoic geological eolution of the SE Asian region: multidisciplinary constraints and implications for biogeography, 25-41. In HALL, R. \& HollowAY, J.D. (eds) Biogeography and geological eolution of SE Asia. Backhuys Publishers, Amsterdam.
NI, S.Z. 1981. Discussion on some problems of Ordovician stratigraphy by means of conodonts in eastern part of Yangtze Gorges Region, 127-134. In MicropalaeONTOLOGiCAL SocietY of ChInA (ed.) Selected Papers of the First Symposium. Science Press, Beijing. [in Chinese]

NI, S.Z. \& LI, Z.H. 1987. Conodonts, 386-447. In WANG, X.F., NI, S.Z., ZenG, Q.L., Xu, G.H., Zhou, T.M., Li, Z.H., XIANG, L.W., LAI, C.G. (eds) Biostratigraphy of the Yangtze Gorges area (2), Early Paleozoic. Geological Publishing House, Beijing. [in Chinese]

Nielsen, A.T. 2004. Ordovician sea level changes: a Baltoscandian perspective, 84-93. In WeBBy, B.D., PARIS, F., Droser, M.L. \& Percival, I.G. (eds) The Great Ordovician Biodiversification Event. 484 pp. Columbia University Press, New York.

OGG, J.G., OGG, G. \& GradsteIn, F.M. 2008. The concise geologic time scale. 150 pp. Cambridge University Press, Cambridge.

Paris, F., Achab, A., Asselin, E., Chen Xiao-Hong, Grahn, Y., Nõlvak, J., Obut, O., Samuelsson, J., Sennikov, N., Vecoli, M., Verniers, J., Wang Xiao-Feng \& Winchester-SeEto, T. 2004. Chitinozoans, 294-311. In Webby, B.D., Paris, F., Droser, M.L. \& Percival, I.G. (eds) The Great Ordovician Biodiversification Event. 484 pp. Columbia University Press, New York.

Ross, R.J. JR., Hintze, L.F., Ethington, R.L., Miller, J.F., TAYLOR, M.E. \& REPETSKI, J.E. 1997. The Ibexian, Lowermost Series in the North American Ordovician, 1-50. In TAYLOR, M.E. (ed.) Early Paleozoic biochronology of the Great Basin, Western United States, U.S. Geological Survey Professional Paper 1579, $115 \mathrm{pp}$.

Schmitz, B., Harper, D.A.T., Peucker-Ehrenbrink, B., Stouge, S., Alwmark, C., Cronholm, A., Bergström, S.M., Tassinari, M. \& WANG, X.F. 2008. Asteroid breakup linked to the Great Ordovician Biodiversification Event. Nature Geoscience 1, 49-53. DOI 10.1038/ngeo.2007.37

Stouge, S., WANG, X.F., Li, Z.H., Chen, X.H. \& WANG, C.S. 2005. The base of the Middle Ordovician series using graphic correlation method. Electronic report, International Subcommission on Ordovician Stratigraphy (ICS-IUGS), http://www.ordovician.cn.

Stouge, S., WAng, Z.H., Wu, R.C. \& Li, Z.H. 2009. Lower to Middle Ordovician conodont faunal diversity on the South China palaeoplate in comparison to the Baltica. Absolutely final meeting of IGCP 503: Ordovician palaeogeography and palaeoclimate, Copenhagen 2009 Abstracts, 18.

SweEt, W.C. 1988. The Conodonta: Morphology, taxonomy, paleoecology and evolutionary history of a long-extinct animal phylum. 212 pp. Oxford Monographs on Geology and Geophysics 10. Clarendon Press, New York, Oxford.

Trotter, J.A., Williams, I.S., Barnes, C.R., Lécuyer, C. \& NICOLL, R.S. 2008. Did cooling oceans trigger Ordovician biodiversification? Evidence from conodont thermometry. Science 321, 550-554. DOI 10.1126/science. 1155814

TuRveY, S.T. 2005. Early Ordovician (Arenig) trilobite palaeoecology and palaeobiogeography of the South China plate. Palaeontology 48(3), 519-547.

DOI 10.1111/j.1475-4983.2005.00468.x

TuRvEY, S.T. 2007. Asaphoid trilobites from the Arenig-Llanvirn of the South China plate. Palaeontology 50(2), 347-399. DOI 10.1111/j.1475-4983.2006.00641.x

TuRveY, S.T. \& ZHOU, Z.Y. 2002. Arenig trilobite associations of Daping, Yichang, Hubei, South China. Acta Palaeontologica Sinica 41(1), 10-18.

Wang, X.F., Hoffnecht, A., Xiao, J.X., Li, Z.H., Chen, S.Q., 
Brocke, R. \& ERdtMann, B.-D. 1993. Thermal maturity of the Sinian and Early Paleozoic in West Hubei, China, assessed by CAI, reflectance and geochemical studies. Stratigraphy and Palaeontology of China 2, 19-50.

Wang, X.F., Li, Z.H., Chen, X.H., \& WAng, C.S. 2003. The Huanghuachang section, potential as Global stratotype for the base of the Middle Ordovician Series, 153-159. In AlBanesI, G.L., Beresi, M.S. \& Peralta, S.H. (eds) Ordovician from Andes. INSUGEO, Serie Correlación Geológica 17.

Wang, X.F., Stouge, S., Chen, X.H., Li, Z.H. \& Wang, C.S. 2009. Dapingian Stage: standard name for the lowermost global stage of the Middle Ordovician Series. Lethaia 42(3), 377-380. DOI 10.1111/j.1502-3931.2009.00169.x

WAng, X.F., Stouge, S., Chen, X.H., Li, Z.H., WANG, C.S., Finney, S.C., Zeng, Q.L., Zhou, Z.Q., Chen, H.M. \& ErdtMANN, B.-D. 2009. The global stratotype section and point for the base of the Middle Ordovician Series and the Third Stage (Dapingian). Episodes 32, 96-113.

Wang, X.F., Stouge, S., ERdtmann, B.-E., Chen, X.H., Li, Z.H., WANG, C.S., Zeng, Q.L., Zhou, Z.Z. \& Chen, H.M. 2005. A proposed GSSP for the base of the middle Ordovician Series: the Huanghuachang section, Yichang, China. Episodes 28, $105-117$.

Wang, X.F., Stouge, S., Erdtmann, B.-E., Chen, X.H., Li, Z.H., WANG, C.S., Stan, C.F., Zeng, Q.L., Zhou, Z.Q. \& ChEN, H.M. 2007. The Global Stratotype Section and Point for the base of the Middle Ordovician Series and the Third Stage: The Huanghuachang GSSP, Yichang, China. 35 pp. http://www.ordovician.cn.

WANG, Z.H. \& BergStröM, S.M. 1995. Castleemainian (Late Yushanian) to Darriwilian (Zhejaingian) conodont faunas, 86-91. In CHEN, X. \& BergströM, S.M. (eds) The Base of the austrodentatus Zone as a level for global subdivision of the Ordovician System. Palaeoworld 5, $117 \mathrm{pp}$.

WANG, Z.H. \& BergströM, S.M. 1998. Conodont-graptolite biostratigraphic relations across the base of the Darriwilian Stage (Middle Ordovician) in the Yangtze Platform and the JCY area in Zhejiang, China. Bolletino della Società Paleontologica Italiana 37, 187-198.

WANG, Z.H. \& BergströM, S.M. 1999. Conodonts across the base of the Darriwilian stage in South China. Acta Micropalaeontologica Sinica 16(4), 325-350. [in Chinese with English abstract]

Wang, Z.H., Bergström, S.M. \& Lane, H.R. 1996. Conodont provinces and biostratigraphy in Ordovician of China. Acta Palaeontologica Sinica 35(1), 26-58.

WANG, Z.H. \& WU, R.C. 2007. Ordovician conodont diversification of Yichang, Hubei Province. Acta Palaeontologica Sinica 46(4), 430-440. [in Chinese with English abstract]

Webby, B.D., Paris, F., Droser, M.L. \& Percival, I.G. (eds) 2004. The Great Ordovician Biodiversification Event. 484 pp. Columbia University Press, New York.

Wu, R.C., Percival, I.G. \& Zhan, R.B. 2010. Biodiversification of early to middle Ordovician conodonts: a case study from the Zitai Formation of Anhui Province, eastern China. Alcheringa 34, 75-86. DOI 10.1080/03115510903343501

Zeng, Q.L., LaI, C.G., Xu, G.H., Ni, S.Z., Zhou, T.M., XIANG, L.W., WANG, X.F. \& ZI, Z.H. 1987. Ordovician, 43-142. In WANG, X.F., NI, S.Z., Zeng, Q.L., Xu, G.H., Zhou, T.M. \& Li, Z.H. (eds) Biostratigraphy of the Yangtze Gorge area (2). Early
Palaeozoic Era. 641 pp. Geological Publishing House, Beijing. [in Chinese with English abstract]

ZenG, Q.L., NI, S.Z., Xu, G.H., Zhou, T.M., WANG, X.F., LI, Z.H., XIANG, L.W. \& LAI, C.G. 1983. Division and correlation of Ordovician System in East Yangtze Gorges Area. Bulletin of the Yichang Institute of Geology and Mineral Resources, CAGS 6, $1-56$.

ZhAN, R.B. \& HARPER, D.A.T. 2006. Biotic diachroneity during the Ordovician Radiation: evidence from South China. Lethaia 39, 211-226. DOI 10.1080/00241160600799770

Zhan, R.B. \& Jin, J.S. 2007. Ordovician-Early Silurian (Llandovery) Stratigraphy and Palaeontology of the Upper Yangtze Platform, South China. 169 pp. Science Press, Beijing.

ZHAN, R.B., Jin, J.S. \& RoNG, J.Y. 2006. $\beta$-diversity fluctuations in Early-Mid Ordovician brachiopod communities of South China. Geological Journal 41(3), 217-288.

DOI 10.1002/gj.1040

ZHAN, R.B. \& RonG, J.Y., 2006. Early to Mid Ordovician brachiopod radiation of South China, 259-283. In RonG, J.Y., FANG, Z.J., Zhou, Z.H., Zhan, R.B., WANG, X.D. \& YuAN, X.L. (eds) Originations, Radiations, Biodiversity Changes - Evidences from the Chinese Fossil Record. 962 pp. Science Press, Beijing. [in Chinese with English abstract]

Zhan, R.B., Rong, J.Y., Cheng, J.H. \& Chen, P.F. 2005. Early-Mid Ordovician brachiopod diversification in South China. Science in China (Series D) 48, 662-675.

ZHANG, J.H. 1996. Lithofacies and stratigraphy of the Ordovician Guniutan Formation in its type area, China. Geological Journal 31, 201-215.

DOI 10.1002/(SICI)1099-1034(199609)31:3<201::AID- GJ691 $>3.0 . \mathrm{CO} ; 2-\mathrm{Q}$

Zhang, J.H. 1997. The Lower Ordovician conodont Eoplacognathus crassus Chen \& Zhang, 1993. Geologiska Föreningens i Stockholm Förhandlingar 119, 61-65.

Zhang, J.H. 1999. Review of the Ordovician Conodont Zonal Index Eoplacognathus suecicus Bergström, 1971. Journal of Paleontology 73(3), 487-493.

Zhang, J.H. 1998. Conodonts from the Guniutan Formation (Llanvirnian) in Hubei and Hunan Provinces, south-central China. Stockholm Contributions in Geology 46, 1-161.

Zhen, Y.Y., Liu, J.B. \& Percival, I.G. 2005. Revision of two prioniodontid species (Conodonta) from the Early Ordovician Honghuayuan Formation of Guizhou, South China. Records of the Australian Museum 57, 303-320.

Zhen, Y.Y., Percival, I.G. \& Liu, J.B. 2006a. Early Ordovician Triangulodus (Conodonta) from the Honghuayuan Formation of Guizhou, South China. Alcheringa 30, 191-212. DOI 10.1080/03115510608619313

Zhen, Y.Y., Percival, I.G. \& Liu, J.B. 2006b. Rhipidognathid conodonts from the Early Ordovician Honghuayuan Formation of Guizhou, South China. Palaeoworld 15, 194-210. DOI 10.1016/j.palwor.2006.07.004

Zhen, Y.Y., Percival, I.G. \& Webby, B.D. 2003. Early Ordovician conodonts from far western New South Wales, Australia. Records of the Australian Museum 55, 169-220.

Zhen, Y.Y., Percival, I.G. \& Zhang, Y.D. 2009. Conodont fauna and biostratigraphy of the Honghuayuan Formation (Early Ordovician) of Guizhou, South China. Alcheringa 33, 257-295. DOI $10.1080 / 03115510903043655$ 